\title{
FACTORS THAT INFLUENCE THE SELECTION OF LEARNING OPPORTUNITIES FOR STUDENT NURSES IN PRIMARY HEALTH CARE
}

\section{Ms H lita}

M.N. Sc

Lecturer, Departement of Nursing, University Of Namibia

\section{Dr U Alberts}

D. Litt et Phil.

Senior lecturer, Department of Advanced Nursing Science, University Of South Africa

\section{Prof. A Van Dyk}

DCur

Dean: Faculty of Medical and Health Sciences, University Of Namibia

Corresponding author: avandyk@unam.na

\section{Dr L F Small}

D.N.Sc

Senior Lecturer, Department of Nursing, University Of Namibia

Key words: Learning opportunities; Primary health care

\section{ABSTRACT}

The researcher, being a nursing lecturer, questioned the method of selection of learning opportunities for student nurses in two training hospitals in the Northern part of Namibia.

The study therefore focused on the following objective: To identify the factors that influence the selection of learning opportunities for primary health care in hospital units. A qualitative research design utilising focus group discussions were used. The population consisted of conveniently selected lecturers, student nurses and registered nurses. The same initial question was asked in each focus group to initiate the discussions. The data were analysed according to Tesch's method.

The results indicated that there is positive commitment from the lecturers and registered nurses to be involved in selecting appropriate learning opportunities. The student nurses also demonstrated a willingness to learn and to be exposed to learning opportunities in primary health care. There were however certain constraints that emerged as themes, namely:

\section{- Managerial constraints}

- Educational constraints

Under the theme "managerial constraints" categories such as workload, nursing staff shortages and communication problems were identified. Under the theme "educational constraints" categories such as a lack of guidance, and the correlation of theory and practice emerged.

Recommendations based on this research report include improvement of in-service education on managerial and educational aspects to facilitate the primary health care approach in hospitals.

\section{OPSOMMING}

Die navorser, uit die aard van haar posisie as 'n verpleegdosent wou bepaal of toepaslike leergeleenthede vir primère gesondheidsorg geselekteer word vir verpleegstudente in twee opleidings hospitale in Namibië.

Die studie was dus op die volgende doelwit gefokus: Die identifikasie van die faktore wat die seleksie van leergeleenthede 
in primêre gesondheidsorg in hospitale beinvloed 'n Kwalitatiewe navorsingsontwerp met die gebruik van fokusgroepbesprekings was aangewend in hierdie studie. Deur middel van gerieflikheidseleksie is dosente, student verpleegkundiges en geregistreerde verpleegkundiges inges/uit in die studie. Dieselfde inisiëringsvraag is by elke fokusgroep gestel om die bespreking in te lei. Die analise van die data is gedoen na aanleiding van Tesch se metode. Uit die bevindings het dit geblyk dat dosente en geregistreerde verpleegkundiges hulle daarmee vereenselwig om toepaslike leergeleenthede te kies, asook om betrokke te raak ten opsigte van verantwoordbare begeleiding. Die studente het hulle bereidwilligheid getoon om te leer en om bloot gestel te word aan primêre gesondheidsorg leergeleenthede. Sekere knelpunte het egter opgeduik wat as temas beskryf is, naamlik:

- Bestuursknelpunte

- Onderrigknelpunte.

Wat betref "bestuursknelpunte" as tema is verskeie kategoriee soos werkslading, verpleegtekorte, en kommunikasie probleme geïdentifiseer. Die tema "onderrigknelpunte" het kategorieë soos 'n gebrek aan leiding, en 'n teorie/praktyk korrelasie gaping bevat. Die aanbevelings van die navorsingsverslag het indiensopleiding met betrekking tot bestuurs en onderrig aspekte aangespreek om die primêre gesondheidsbenadering te bevorder in hospitale.

\section{INTRODUCTION AND BACKGROUND TO THE PROBLEM}

The years immediately after independence in 1990 were characterised by efforts to install or adopt a primary health care approach in Namibia. This was necessary for equitable distribution of resources and for equity of access to basic services for as many persons as possible.

To ensure that the transition was organised and ran smoothly, guidelines were issued by the government of Namibia. According to the national primary health care guidelines in Namibia, primary health care should include at least:

- $\quad$ Education concerning prevailing health problems and the methods to prevent and control them.

- Promotion of food supply and proper nutrition, as well as adequate and safe water supply.

- Basic sanitation.

- Maternal and child health care including family planning, immunisation against major diseases, appropriate treatment of common diseases and injuries and provision of essential drugs, as well as community participation in health and social matters (Ministry of Health and Social Services, Namibia; 1992:4).

Although the shift in emphasis to primary health care implies more emphasis on community placement of students, students are mostly placed in the hospital setting to acquire clinical skills, and not in the community. This is also the case in the North West Region of Namibia where student nurses are located in hospitals for most of their time to obtain and master their clinical skills. These skills should link up with the primary health care approach as envisaged by the Government of Namibia. In 1995 the Faculty of Medical and Health Sciences in collaboration with the Ministry of Health and Social Services revised the nursing curriculum in order to include these skills to provide comprehensive health care (UNAM, 1995:8).

This change to a more primary health care oriented approach in the curriculum meant that learning opportunities and guidance, specifically related to primary health care, must also be available in hospitals. Yet there is not sufficient evidence that everyone concerned exactly understands how to provide for learning opportunities with regard to primary health care.

To add to the problem, some nurses can't see the place of curative services, more specifically the role of the hospital in this regard. Another reason could be that hospitals do not view their responsibilities as extending to the population outside its walls. This leads to a situation where preventative, curative and rehabilitative services are seen as different pillars and not as a whole (Ebrahim \& Ranken, 1995:12).

Also, in the past, students were allocated by student administrative officers to the different hospital wards in collaboration with the concerned lecturers. The selection of learning opportunities were not planned or structured. 
Unfortunately, these factors might create stumbling blocks when it comes to the selection of learning opportunities for a primary health care approach in hospitals.

\section{PROBLEM STATEMENT}

It is not clear how learning opportunities for primary health care are selected for student nurses in the hospital setting.

\section{RESEARCH QUESTION}

To focus the study, the researcher has stated the following research question:

- How are learning opportunities for the primary health care approach in hospital units selected by registered nurses and lecturers for student nurses?

One of the objectives stated for the study, in order to obtain answers to the question, was:

- To identify the factors that influence the selection of learning opportunities for primary health care in hospital units.

\section{DEFINITION OF CENTRAL CONCEPTS}

Learning opportunities: The possibilities for learning created by the registered nurse or midwife in the classroom and clinical teaching situation (Mellish \& Brink, 1990:118).

Primary health care: The essential care made universally available to individuals and families in the community by means acceptable to them, through their full participation and at a cost that the community and the country can afford (Searle, Brink \& Grobbelaar, 1991:141).

\section{RESEARCH DESIGN}

A qualitative exploratory descriptive design that was contextual in nature, was used.

\section{POPULATION AND SAMPLING}

The target population consisted of three groups:

- Student nurses following the four year diploma in "Comprehensive Nursing and Midwifery Science" at the two training hospitals in the North West Region of Namibia.

- $\quad$ Registered nurses who were working in direct patient care at the two specific hospitals in departments where student nurses were allocated.

- $\quad$ All the lecturing staff of the Department of Nursing that were entrusted by the University of Namibia to educate student nurses in these two hospitals.

The researcher sought student nurses, registered nurses and lecturers who were willing to describe their experiences or their ideas. The motivation was that they would feel at ease to contribute, and because they were willing meant that they perhaps already had opinions that they felt should be heard. Thus, by means of convenient sampling forty one (41) participants agreed to be interviewed. (See table 1)

Table 1: Outline of the sample

\begin{tabular}{|c|c|c|}
\hline \multicolumn{3}{|c|}{ HOSPITAL A } \\
\hline Group 1 & Registered nurses & 7 \\
\hline Group 2 & Lecturers & 4 \\
\hline Group 3 & Student nurses & 9 \\
\hline \multicolumn{3}{|c|}{ HOSPITAL B } \\
\hline Group 4 & Registered nurses & 9 \\
\hline Group 5 & Lecturers & 3 \\
\hline Group 6 & Student nurses & 9 \\
\hline \multicolumn{2}{|l|}{ TOTAL } & 41 \\
\hline
\end{tabular}

The four groups of lecturers and student nurses preferred to have their focus group discussions conducted in English (Groups 2, 3, 5 and 6), while the two groups of registered nurses preferred to have their focus group discussions conducted in Oshiwambo. The data of the latter were translated into English by the researcher.

\section{DATA COLLECTION}

Data were collected by means of focus group 
discussions. It was felt that focus group discussions would be more informative as it might create prompting of experiences and ideas from the participants. In a "one to one" interview the participants might also have felt intimidated by the lecturer. This was particularly considered with regard to the student nurses.

The initial question to start the discussions and to attain the previously stated objective was: "Tell me the factors that influence the selection of learning opportunities for student nurses in primary health care in hospital units". This question was used in all six focus group interviews as will be explained further on.

Each focus group interview was audio taped and transcribed. Field notes were kept to document these discussion sessions as well as the experience of the researcher.

Follow-up meetings were also conducted with the participants to confirm whether the information, which the researcher came up with was a real reflection of what the participants meant.

During the discussions the researcher used certain communication skills to ensure that the participants express their views freely, namely restating, validating, active listening, and minimal verbal response (Rawlins, Williams \& Beck, 1993:97-101).

\section{DATA ANALYSIS}

Data from the focus group interviews were analysed according to Tesch's method (in Cresswell, 1994:155). In short this method entails the following:

- Listening to the taped information to get a sense of the whole.

- Transcribing all the taped interviews word by word.

- $\quad$ Reading through all the transcriptions and jotting down some ideas.

- $\quad$ Picking the most interesting and shortest interview, and analysing its content.

- Analyse the other transcripts.

- List all topics and cluster similar ones together as themes.

- Reorganising the data - abbreviate topics as codes and writing the codes to appropriate segments in the different texts.

- $\quad$ Organising of a scheme to see if new categories and codes would arise.

- $\quad$ Performing a preliminary analysis.

- Peer group analysis.

The researcher and the study promoters were engaged in the coding of the data.

\section{TRUSTWORTHINESS}

The principles for trustworthiness were applied as described by Guba and Lincoln, 1991 (in Krefting, 1991:215).

Table 2 summarises the strategies the author applied to ensure trustworthiness.

\section{ETHICAL CONSIDERATIONS}

Written consent was obtained from the office of the permanent secretary of the Ministry of Health and Social Services to conduct this research. The respondents were informed about the purpose of the research and that they could withdraw at any time. Anonymity and confidentiality was also ensured.

\section{DISCUSSION OF THE RESULTS}

The relevant literature control is integrated in the discussions to follow.

The discussions are organised around the identified themes and categories. Two themes emerged from the data with regard to the stated objective, as depicted in table 3, namely:

- Managerial constraints, and

- Educational constraints.

\section{Managerial constraints}

\section{Workload and shortage of personnel}

During the discussions it was mentioned by participants that the workload of the personnel limited the availability to teach and guide students on the primary health care approach. 
Table 2: Strategies to ensure trustworthiness

\begin{tabular}{|c|c|c|}
\hline STRATEGY & CRITERIA & APPLICATION \\
\hline \multirow[t]{5}{*}{ Credibility } & Prolonged engagement & $\begin{array}{l}\text { Researcher had more than } 5 \text { years } \\
\text { experience as a lecturer and is well } \\
\text { conversed with aspects of primary health } \\
\text { care. }\end{array}$ \\
\hline & Persistent observation & - Utilised rephrasing and repeated questions. \\
\hline & Member checking & $\begin{array}{l}\text { - Follow-up meetings conducted after the data } \\
\text { was coded. }\end{array}$ \\
\hline & Structural coherence & $\begin{array}{l}\text { - Focused on primary health care educational } \\
\text { aspects only. }\end{array}$ \\
\hline & Authority or researcher & $\begin{array}{l}\text { - Researcher well versed in group dynamics } \\
\text { to capture the contextual understanding of } \\
\text { the respondents experience. }\end{array}$ \\
\hline Transferability & Dense description & $\begin{array}{l}\text { - Not applicable. Dense data descriptions were } \\
\text { obtained }\end{array}$ \\
\hline Dependability & $\begin{array}{l}\text { Dense description of the } \\
\text { methodology }\end{array}$ & $\begin{array}{l}\text { - Research methodology clearly and fully } \\
\text { described. } \\
\text { - Field notes were kept and referred to. } \\
\text { - All the materials used during the study were } \\
\text { kept. }\end{array}$ \\
\hline Confirmability & Confirmability & Audit by an independent researcher. \\
\hline
\end{tabular}


Table 3: Identified themes and categories

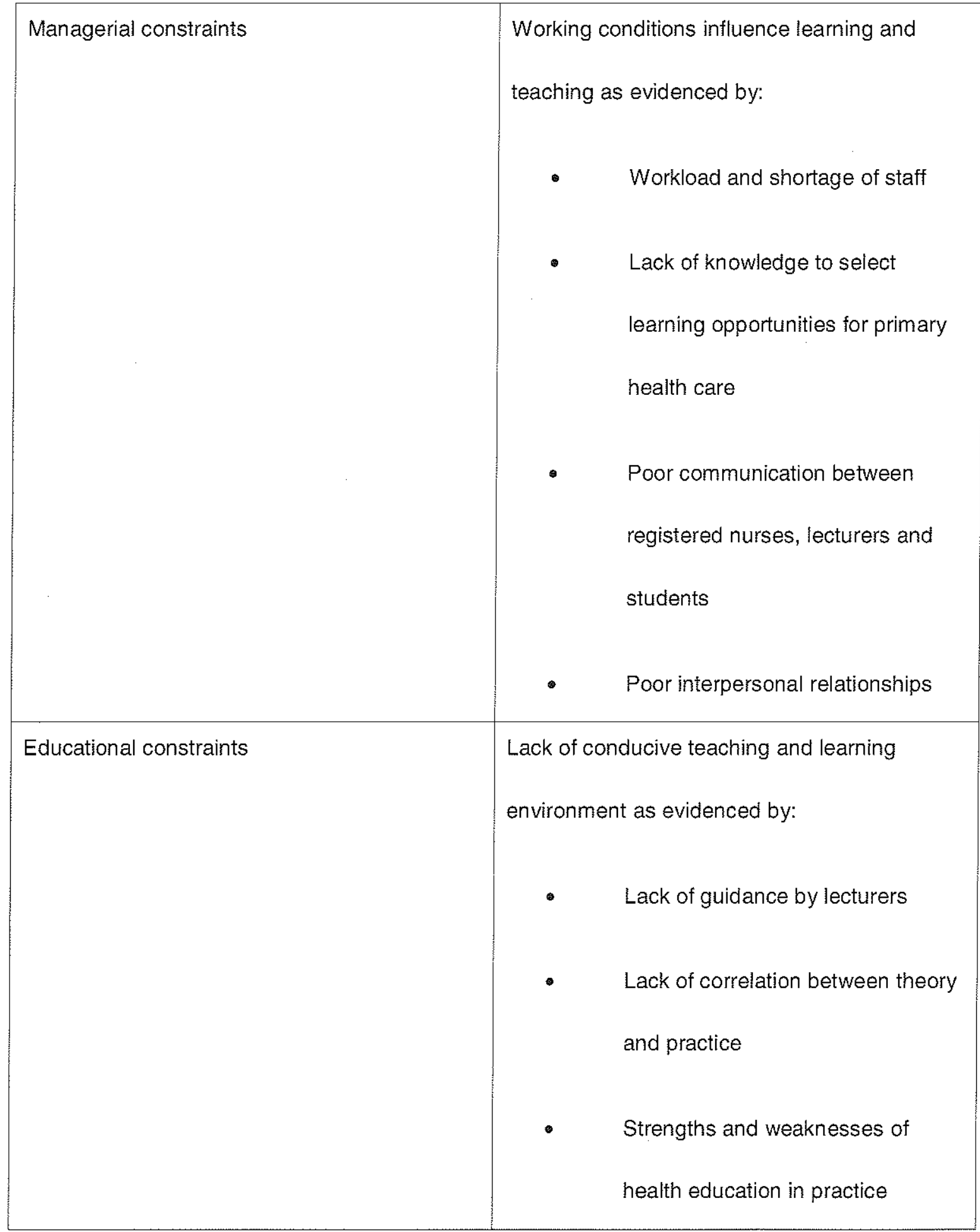

As one registered nurse commented: "In the hospital we have very few registered nurses. We don't always have the time to guide and teach students properly that are allocated to our wards" (sic). Another registered nurse stated: "Our hospital is serving many patients, therefore time for teaching is limited. I doubt whether the learning climate is always conducive for learning of primary health care principles" (sic).
These findings correlate with those of a study that was done by Fish \& Purr (in Quinn, 1998:186). In their evaluation of practice-based learning in continuing professional education in nursing, they concluded that supervisors had heavy workloads and that their roles were not very well defined.

Proper organisation of personnel and time to supervise 
and guide students during clinical sessions is important. This aspect is emphasised by Quinn (1998:186) who stated that students should be supervised and guided by first level nurses who have received preparation in this regard, to ensure that relevant experiences are provided for students.

To link to the abovementioned referral from the literature, the concept of a "teachable moment" should be explored. This is the view of Mellish, Brink \& Paton (1998:140). A teachable moment occurs in real life situation without previous planning.

\section{Lack of knowledge to select learning opportunities}

According to Mashaba \& Brink (1994:131) one of the important issues in creative management in the practice setting is the types of knowledge and skills that are selected to be developed.

Registered nurses and lecturers are considered to be the resource persons who could take a lead in the coordination of student nurses' education and guidance. However, it was reported from all the participants (registered nurses, lecturers and students) that this guidance is not always sufficient. It was also revealed that not all concerned are sure about how to select primary health care learning opportunities in the ward. This was demonstrated by comments from the students, as is quoted from one student nurse: "On the primary health care approach, concerning the wards, it seems as if the primary health care approach is really known by people who are working in primary health care departments like the antenatal clinic, but as far as the general hospital departments are concerned, I think they are just concerned with treatment of patients" (sic). Another student nurse added to this by saying: "In the case of primary health care, we are being taught by registered nurses in the wards how to do service according to the information they have which is not always sufficient" (sic).

According to Palmer, Burns \& Bulmon (1994:15) the practical situation focuses on competence and the development of reflection, therefore the approaches to learning must be congruent with this. But it seems as if students do not always have the courage to ask. This was reflected by a student who said: "Some learning opportunities are not utilised because we don't really ask registered nurses to teach us some primary health care procedures when they are not busy" (sic). A lecturer said: "I don't think we are all really clear about how to implement or how to integrate the primary health care approach in the subjects that we teach during clinical sessions."

This is a problematic situation. According to Mellish \& Brink (1990:94), the one thing that makes a person a successful teacher is that one should, among all other requirements, be knowledgeable and up to date with his or her subject and be able to bridge the gaps between the world of the student, and the real world, theory and practice.

\section{Poor communication between registered nurses, lecturers and students}

Some of the participants indicated that poor communication sometimes creates stumbling blocks in the guidance of students. This resulted in a situation where lecturers and registered nurses did not always communicate with each other and with the students about what they should learn and practice. This is evident from the following comment of a student nurse: "Sometimes there is no communication between lecturers and registered nurses in the clinical situation. This creates problems for students in achieving objectives in the clinical setting" (sic).

Communication forms a crucial part of the effective management of every unit. Without effective communication none of the steps in the management process can be implemented effectively (Naude, Meyer \& van Niekerk, 1999:192).

To demonstrate just how important effective communication is, Horne and Cowan (1992:1) stressed that effective communication is an undeniable element of every situation for goals to be achieved.

The students also indicated that their progress reports were not always communicated to them - that they did not always receive feedback.

\section{Poor interpersonal relationships}

It was mentioned by the student nurses that the interpersonal relationships between registered nurses 
and students were not always what it should be. This could have a demotive implication. One student captured the situation as follows: "The attitudes of registered nurses in the wards do sometimes cause frustration for the students, because they will shout at you in front of a patient if you make a mistake" (sic). Adding to this another student said: "If you see a registered nurse do a procedure on a patient and you asked to be involved, the registered nurse says: 'Go away, I don't want to be surrounded by students" (sic). This is a complex situation for a student, because it might lead to avoidance of "opportunity/learning seeking behaviour."

It might happen that the nurse might also become discouraged or he or she might display inappropriate professional behaviour. Like one registered nurse who made the following remark: "I really don't know whether students are taught ethics anymore, because / don't see them applying it to practice" (sic).

Sometimes interpersonal conflict arises between student nurses and registered nurses. Clashes of personality occur from time to time. Student nurses may experience problems with their studies, and clinical practice, as well as the developmental stages of their age group. Quinn (1998:182) suggests that students should be treated with kindness and understanding by qualified personnel.

\section{Educational constraints}

This theme emerged from descriptors that indicate an environment that was not conducive to teaching and learning. The categories to support this theme are:

- lack of guidance by lecturers

- lack of correlation between theory and practice

- health education issues

\section{Lack of guidance by lecturers in the clinical area}

Lecturers are seen as the educational leaders and resource persons, but it also became evident that they did not provide the necessary guidance to the registered nurses in the wards concerning the curriculum outline.

Some of the registered nurses were of the opinion that lecturers were not always available to guide student nurses and registered nurses concerning learning experiences for primary health care in the wards.
One registered nurse had the following question: "Why don't lecturers come more often to the clinical setting to spend time together with students and registered nurses to guide us in the selection of learning opportunities for primary health care?" (sic).

This problem is also documented in the literature. Campbell (1991:39) states that the correlation between theory and practice was unsatisfactory and that clinical teaching was usually done in a disorganised manner.

That registered nurses were not always informed about curriculum issues is also demonstrated by the following remark of a registered nurse: "Practice programmes for student nurses are not always clear for us in the wards. What is not clear for us is what students on different levels should know and learn regarding primary health care" (sic).

Some of those problems can be avoided by adequate planning and preparation. This includes both the student nurses and the clinical personnel (Ewan \& White, 1996:116). In this study "clinical personnel" might just as easily be replaced by registered nurses. Proper planning might alleviate the following problem as aired by a student nurse: "Some of the information that is given by lecturers on primary health care is not always known by the staff in the wards. Because of this registered nurses find it difficult to guide us, the students" (sic).

\section{Lack of correlation between theory and practice}

The students who participated in this study indicated that they have experienced problems with the correlation between theory and practice specifically with regard to practical procedures and health education. As one student states it: "When we as student nurses try to do things as we were taught in the class, the staff in the wards felt that we are wasting time, while there is still much to do for example if you want to apply family planning protocols for instance" (sic).

This problem was also expressed from the viewpoint of the lecturers. One lecturer had this to say: "Student nurses are being taught how to do the correct procedures at the college, but by the time they go to the clinical situation, they start again to learn other methods of doing procedures incorrectly and it seem as if they get confused 
as they don't know anymore which is the correct way of doing procedures. Students nurses don't do procedures as they were taught at the college ... resulting in two ways of doing things."

According to Wilkinson (1998:89) correlation between theory and practice is important due to the fact that diagnostic reasoning, which is based on a theoretical background, is used to analyse data and draw conclusions about the patient's health status.

Contributing to the expressed problem of the gap between theory and practice is the lack of equipment. One student nurse gave the following example: "I think also ... some of the problems are just coming from the equipment, especially when they are teaching you how to make ... how to prepare a feeding for the baby pack. They (at the ward), just prepare the feeding without a gown, without a cap, without a mask, then you must only learn the procedure which is not systematic," (sic).

This issue is supported by the following remark from a registered nurse: "Another thing is that we don't have enough or all equipment in the hospital which is necessary to teach these student nurses. It may happen that I am teaching the student nurses a certain procedure but I may find that some of the instruments listed in the instrument bundle to be used are not all available in our hospital."

Quinn (1998:185) indicated that for any environment to be good for proper student learning during their practical placements, it should be adequate in terms of space and necessary equipment as well as safety so as to facilitate development of competency.

Rolfe (1996:1) stated that the problem of the theory practice gap is one of the most problematic and enduring issues for nursing. This so called "theory practice gap" is probably felt most accurately by student nurses, who often find themselves torn between the demands of their tutors to implement what they have learned in theory, and pressure from practicing nurses to conform to the constraints of real life clinical situations.

\section{Health education issues}

Health education is an essential ingredient of primary health care, and should be implemented in the hospital wards. The fact that patients are discharged earlier places more responsibilities onto the patients themselves, their families and home-based caretakers.

Although the participants indicated that health education has been done, some shortcomings were also pointed out. This creates a stumbling block in learning opportunities for students. One student had this to say: "In the medical ward we provide information to the patients in terms of their treatment but we really don't include the families of our patients as it is being emphasised" (sic).

According to Canobbia (1996:xxiv) patients often may not feel prepared for, or physically capable of performing self-care activities. Consequently, family members are the vital links in the transition from hospital to home care. Families need to be included in all discussions and demonstrations.

There should thus be a proper system concerning health education in place through which students can get enough opportunities and experience to give proper health education.

\section{SUMMARY}

It was stated by registered nurses that they were willing to take part in the education of students. They wanted students to eventually become competent and selfdirected registered nurses. However they revealed that there were some managerial problems when it came to the creation of learning opportunities. The registered nurses expressed the problem of workload and personnel shortages, uncertainty as to the implementation of primary health care in hospitals, poor communication between the different role players, as well as poor interpersonal relationships.

It was also evident that the environment was not always conducive for learning and teaching. This was caused by a lack of guidance on how learning opportunities should be selected to emphasise primary health care. A gap between theory and practice as well as weaknesses concerning health education were mentioned.

It was evident that registered nurses in the wards were not always sure how to guide the students concerning primary health care. It was also pointed out that lecturers 
did not provide enough guidance to registered nurses in this regard.

\section{RECOMMENDATIONS}

The recommendations from this study were made with specific reference to nursing education and the management of primary health care implementation in the hospital units/wards.

\section{Nursing Education}

An environment conducive to learning during clinical sessions needs to be established. A psychological environment, where good interpersonal relationships are fostered, needs to be promoted as well (Lathlean \& Vaughan, 1994:55).

This could be achieved through the issuing of specific objectives related to primary health care. This should be coupled with a macro and micro orientation of the hospital unit or wards. Furthermore, the content, objectives and expectations of the educational programmes should also be explained to the registered nurses in the hospital units or wards. Discussions, orientation sessions or regular meetings between the concerned parties could only enhance the possibility of success.

The importance of a thorough orientation to the registered nurses in the wards might be the most important consideration. This aspect is also emphasised by Ewan and White (1996:110) who stated that if clinical supervisors are not fully aware of the objectives, or the background knowledge and skills of students, they will have little opportunity to achieve the objectives for which the placement was intended.

Registered nurses in the wards should be guided on the selection of learning opportunities for students in the wards. Opportunities must also be provided for reflection and dialogue on experiences such as making errors, discovering diversity and future actions. According to Rolfe and Fulbrook (1998:231) students must feel free to make mistakes and to voice their misconceptions. Students should also be encouraged into higher thinking modes such as analysis, critiquing, evaluating, assumptions and inquiring into the nature of things concerning primary health care (Karlowitz, 2000:82). For the registered nurse to be competent in the abovementioned, it might be necessary to provide inservice education sessions.

\section{Nursing management of primary health care in hospitals}

In this regard the essential requirement is effective communication between the students, lectures and registered nurses in the wards. A regular forum is but one way to achieve this goal. Registered nurses should be invited to participate in curriculum discussions and evaluations.

The clinical setting must be managed in such a manner as to allow students to plan their own learning. This means a fine balance between flexibility for individual student projects, but also enough structure and guidance to prevent deviation from the ultimate purpose (Ewan \& White, 1996:117). Learning contracts could contribute to better planning and time management.

\section{LIMITATIONS OF THE STUDY}

Limitations applicable to this study are participant effect, and data collection and analysis.

\section{Participant effect}

It is possible that the participants may have answered questions in a manner which they perceived as being more polite, and not really expressed their true feelings or ideas.

\section{Data collection and analysis}

For two of the six focus group discussions conducted, the discussions were conducted in Oshiwambo, and it was therefore necessary to translate the data into English. This translation might have resulted in distorting the originality of the participants experience as expressed in their original language.

\section{CONCLUSION}

It appears as if the optimal selection of learning opportunities on primary health care for students nurses in certain hospitals in Namibia is not being accomplished. 
The student nurses vocalised a perception of not being adequately guided and taught by lecturers and registered nurses in the selection of learning opportunities. These "drawbacks" can however be addressed and rectified by forum discussions and planning meetings.

\section{BIBLIOGRAPHY}

Campbell, C 1991: Improving Staff nurse participation. Nursing Administration Quarterly, 16(1):56-60.

Canobbia, MM 1996: Handbook of Patient Teaching, includes home care. University of California: Mosby.

Cresswell, JW 1994: Research design: Qualitative and quantitative approaches. London: Sage Publications.

Ebrahim, GJ \& Ranken, JP 1995: Primary Health Care: Reorienting Organisational support; first edition. London: Macmillan Education. Ltd.

Ewan, CL \& White, R 1996: Teaching Nursing. A self instructional handbook. London: Chapman \& Hall.

Horne, EMR \& Cowan, T 1992: The professional development series. Effective Communication. Some nursing perspective; second edition. England: Wolfe Publishing Ltd.

Karlowitz, KA 2000: The value of student portfolios to evaluate undergraduate nursing programs. Nurse Educator, 25(2):82-87.

Krefting, L 1991: Rigor in qualitative research. The assessment of trustworthiness. The American Journal of Occupational Therapy, 45(3), March.

Lathlean, J \& Vaughan, B 1994: Unifying Nursing Practice and theory. Oxford: Butterworth - Heinemann.

Mashaba, TG \& Brink, HI 1994: Nursing Education. An international perspective. University of South Africa: Juta \& Co Ltd.

Mellish, JM \& Brink, H 1990: Teaching the practice of nursing. A text in nursing didactics; third edition. Durban: Butterworths

Mellish, JM; Brink, H\& Paton, F 1998: Teaching the practice of nursing. A text in nursing didactics. Durban: Butterworths.

Ministry of Health and Social Services, Namibia 1992: Official National Primary Health Care/Community Based Health Care Guidelines. Windhoek: John Meinert Printing.

Naude, M; Meyer, SM \& Van Niekerk, SE 1999: The Nursing Unit Manager: A comprehensive Guide. Heinemann: Sandton.

Paimer, AM; Burns, SI \& Bulmon, C 1994: Reflective practice in nursing. London: Blackwell Scientific Publications.

Quinn, FM 1998 : The principles and practice of nurse education. London: Chapmann and Hall.

Rawlins, RP; Williams, SR \& Beck, CK 1993: Mental Health Psychiatric Nursing. A Holistic Life Cycle. St Louis: Mosby

Rolfe, G 1996: Closing the Theory - Practice Gap. A new paradigm

for nursing. Oxford: Butterworth.
Rolfe, G \& Fulbrook, P 1998: Advanced Nursing Practice; first edition. Oxford: Butterworth.

Searle, C; Brink, H \& Grobbelaar, WC 1991: Aspects of Community Health. Cape Town: King Edward VII Trust.

University of Namibia, Faculty of Medical and Health Science 1995: Diploma in Comprehensive Nursing and Midwifery Science (Updated Curriculum). Windhoek: University of Namibia.

Wilkinson, JM 1998: Nursing Process - A critical thinking approach. California: Addison-Wesley. 